\title{
Effects of Jamaican cherry (Muntingia calabura L.) Fruits Extract on Immunoglobulin G Levels and Hematological Profiles in Mice
}

\author{
Tanti Azizah Sujono ${ }^{1, *}$, Ika Trisharyanti Dian Kusumowati ${ }^{2}$, Rima Munawaroh ${ }^{3}$
}

Tanti Azizah Sujono ${ }^{1, *}$, lka Trisharyanti Dian Kusumowati ${ }^{2}$, Rima Munawaroh ${ }^{3}$

'Department of Pharmacology and Clinical Pharmacy, Faculty of Pharmacy, Universitas Muhammadiyah Surakarta, 57162 INDONESIA.

${ }^{2}$ Department of Pharmaceutical Chemistry,

Faculty of Pharmacy, Universitas

Muhammadiyah Surakarta, 57162, INDONESIA.

${ }^{3}$ Department of Biology Pharmacy, Faculty of Pharmacy, Universitas Muhammadiyah Surakarta, 57162, INDONESIA.

\section{Correspondence}

\section{Tanti Azizah Sujono}

Department of Pharmacology and Clinical Pharmacy, Faculty of Pharmacy,

Universitas Muhammadiyah Surakarta,

57162, INDONESIA.

E-mail: tanti_azizah@ums.ac.id

History

- Submission Date: 18-12-2020;

- Review completed: 26-12-2020;

- Accepted Date: 07-01-2021.

DOI : 10.5530/pj.2021.13.67

Article Available online

http://www.phcogj.com/v13/i2

Copyright

(c) 2021 Phcogj.Com. This is an openaccess article distributed under the terms of the Creative Commons Attribution 4.0 International license.

\section{ABSTRACT}

Background: Jamaican cherry (Muntingia calabura L.) fruits contain potential immunomodulatory agents such as phenolic and flavonoid compounds. However, previous research was limited only to the effect of Jamaican cherry fruits on non-specific immune response namely the phagocytic index. Objective: This study aims to determine the immunomodulatory activity of Jamaican cherry fruits against specific immune response by measuring the antibody formation named immunoglobulin $\mathrm{G}(\lg \mathrm{G})$. In addition, the hematological profile of the animals induced by hepatitis $B$ vaccine was also evaluated. Materials and methods: forty male mice were grouped into 8 groups consist of control, treatment, and standard groups. Control group was given CMC-Na 0.5\%, six treatment groups were each given either the methanol extract of Jamaican cherry fruits (MEJF), or ethyl acetate fraction of Jamaican cherry fruits (EAJFJ) with the doses of 50, 100, and 200 $\mathrm{mg} / \mathrm{kg}$ BW (each dose for one group), and levamisole was given to the standard group. Levamisole and extract of Jamaican cherry fruits were prepared as a suspension in CMC$\mathrm{Na} 0.5 \%$ and administered orally for 15 days. Mice were induced with hepatitis $\mathrm{B}$ vaccine intraperitoneally twice. The levels of $\mathrm{IgG}$, hematological profiles, and organ index were measured on the $16^{\text {th }}$ day. Results: The administration of MEJF and EAFJF stimulated IgG production significantly compared to the control group $(p<0.05)$. Meanwhile, the MEJF and EAFJF did not influence the hematological profile. An increase of the spleen index was found in the EAFJF group compared to the control. Both MEJF and EAFJF were shown to have flavonoids, phenolics, and triterpenoids contents. Conclusion: MEJF and EAFJF possessed immunostimulant properties by increasing the specific (humoral) immune response (IgG) after induction with the hepatitis B vaccine.

Key words: Jamaican cherry (Muntingia calabura L.), Immunoglobulin G, Hepatitis B vaccine, Hematological profile.

\section{INTRODUCTION}

Immunomodulators are substances that can help to regulate or normalize the immune system. Immunomodulators are able to enhance the immune response in individuals with incompetent immune systems as in HIV/AIDS, allergies, and cancer patients. On top of that, the use of immunomodulators will help to normalize the excessive immune response in a patient with autoimmune disease ${ }^{1}$. Some studies have shown that some food and plant materials can modulate and activate the immune system function. Currently, many people are interested in "back to nature" using herbal medicines because they are considered to have relatively milder side effects compared to the modern medicine. One of the plants that are known in the community to have some health benefits is Jamaican cherry.

Jamaican cherry fruits are well-known plants that possess some pharmacological activities such as anti-inflammatory properties ${ }^{2}$, as well as antirheumatic ${ }^{3}$, antioxidants ${ }^{4-6}$, antidiabetic ${ }^{7}$, and immunomodulators ${ }^{8}$. Several compounds such as polysaccharides, flavonoids, alkaloids, lactones, diterpenoids, and glycosides have been reported to possess immunomodulatory effects 9 .
Jamaican cherry fruit is thought to have an immunomodulatory effect because of its flavonoids ${ }^{10}$ and phenolic compound (gallic acid) ${ }^{11-13}$. The mechanism of the immunomodulatory effect of Jamaican cherry fruit is still unknown. Previous studies have shown that methanol extract and ethyl acetate fraction of Jamaican cherry (Muntingia calabura L.) have immunomodulatory effects on non-specific immune response by increasing the phagocytic index using carbon clearance methods ${ }^{8}$.

However, until now there have been no studies that tested the immunomodulatory activity of Jamaican cherry fruits on specific immune responses. The specific immune system consists of the humoral and cellular systems. B lymphocytes play a major role in the humoral immune system. B cells stimulated by antigens will proliferate, differentiate, and develop into plasma cells that produce antibodies. Antibodies function to defend against extracellular, viral, and bacterial infections and neutralize toxins ${ }^{1}$. Antibodies are globulin proteins (immunoglobulins) that react specifically with antigens that stimulate their production. Immunoglobulin G (IgG) is the main immunoglobulin in human blood serum which makes up about up to $75 \%$ out of all immunoglobulins ${ }^{1}$.
Cite this article: Sujono TA, Kusumowati ITD, Munawaroh R. Effects of Jamaican cherry (Muntingia calabura L.) Fruits Extract on Immunoglobulin G Levels and Hematological Profiles in Mice. Pharmacog J. 2021;13(2): 535-41. 
Therefore, it is important to determine the immunomodulatory activity of Jamaican cherry fruit extract on specific immune response by measuring the IgG production in vaccine $B$ induced mice.

\section{MATERIALS AND METHODS}

\section{Materials}

Ethyl acetate, methanol, n-hexane, dichloromethane (Merck), carboxymethylcellulose $\mathrm{Na}$, Levamisole (PT Konimex Solo, Indonesia), hepatitis B vaccine (Engerix ${ }^{\mathrm{TM}}-\mathrm{B}$, Glaxo Smith Kline), IgG Mouse (Immunoglobulin G) ELISA Kit (FineTest, Wuhan China), EDTA (titriplex III, Merck).

\section{Animals}

Male Swiss mice were purchased from the Faculty of Pharmacy, Universitas Muhammadiyah Surakarta, Indonesia (weight 20-25 g, age 8-10 weeks). Mice were housed under standard laboratory conditions with a temperature of $21 \pm 2^{\circ} \mathrm{C}, 12 \mathrm{~h}$ of light and $12 \mathrm{~h}$ of dark cycles, with the relative humidity of $55 \pm 10 \%$. Mice were given standard pellet as feed and water ad libitum. The acclimatization of mice was carried out for 1 week before the research began. The number of mice used and all experimental protocols for this study were approved by the ethics committee of the Faculty of Medicine, Universitas Muhammadiyah Surakarta, with approval number: 2392/A.2/KEPK-FKUMS/IX/ 2019.

\section{Collection and identification of plant}

Jamaican cherry fruits were collected from Bantul, Yogyakarta, Indonesia during the dry season. Identification of Jamaican cherry (Muntingia calabura L.) plant was done at the Pharmacognosy laboratory of Pharmaceutical Biology department, Faculty of Pharmacy, Universitas Gadjah Mada, Yogyakarta (No: 18.2.9/UN1/FFA/BF/PT/2019).

\section{Extraction of Jamaican cherry fruits}

The ripened of Jamaican cherry fruits were cleaned under the running water then drained and dried in the oven at $45-50^{\circ} \mathrm{C}$ for 1 week. The dried Jamaican cherry fruits were pulverized and macerated with methanol in a ratio of 1:7 for 3 days. The filtrate was evaporated to obtain viscous methanol extract. Liquid-liquid fractionation was carried out on the crude methanol extract using solvents with different polarities (n-hexane, dichloromethane, and ethyl acetate) from nonpolar to semipolar solvent respectively. Then all soluble fractions were concentrated to obtain viscous fraction.

\section{Phytochemical screening}

Preparation of sample for phytochemical screening with a concentration of $1 \%$ (extract of $250 \mathrm{mg}$ dissolved in $25 \mathrm{~mL}$ solvent).

\section{a. Flavonoid identification}

A total of $1 \mathrm{~mL}$ of sample was put into a test tube, then 2 drops of $10 \% \mathrm{NaOH}$ were added and shaken vigorously. The sample contains flavonoids if the solution turns yellow, red, or brown ${ }^{14}$.

\section{b. Alkaloid identification}

$2 \mathrm{~mL}$ of sample was evaporated, then the residue was dissolved in $4 \mathrm{~mL}$ $2 \mathrm{~N} \mathrm{HCl}$. The solution was separated into 3 different tubes of $1 \mathrm{~mL}$ each, namely tubes A, B, and C. Tube A as a blank without adding anything. Tube $\mathrm{B}$ was added 3 drops of Mayer's reagent, if a white precipitate is formed, the sample contains alkaloids. Tube $\mathrm{C}$ was added with Dragendrof reagent 3 drops, if brownish-orange sediment is formed, the sample contains alkaloids ${ }^{14}$.

c. Identification of tannins (polyphenols)

A total of $1 \mathrm{~mL}$ of sample was put into a test tube and then it was added 1 drop of $5 \% \mathrm{FeCl}_{3}$ solution. The presence of tannins (polyphenols) in the sample is indicated by the formation of a green, red, purple, blue, or solid black solution ${ }^{14}$.

d. Steroid and Terpenoid Identification (Liebermann-Burchard test)

$1 \mathrm{~mL}$ of sample was added $1 \mathrm{~mL}$ of anhydrous acetic acid then added concentrated $\mathrm{H}_{2} \mathrm{SO}_{4}$. The presence of terpenoids is indicated by the formation of a brownish ring, while the presence of steroids is indicated by the formation of a turquoise ring ${ }^{14}$.

\section{e. Saponin identification}

$1 \mathrm{~mL}$ of sample was shaken vertically for 10 seconds then left for 10 seconds. The formation of stable foam as high as $1-10 \mathrm{~cm}$ will form in no less than 10 minutes. Then it was added 1 drop of $2 \mathrm{~N} \mathrm{HCl}$, if the foam does not disappear, it indicates the presence of saponins.

\section{Experimental design}

This study used a post-test only design with a control group. A total of 40 male mice were randomly divided into 8 groups, consisting of 5 mice for each group, namely control (CMC-Na $0.5 \%$ ), methanol extract of Jamaican cherry fruits (MEJF), and ethyl acetate fraction of Jamaican cherry fruits (EAFJF) at doses of 50, 100, and $200 \mathrm{mg} / \mathrm{kg} \mathrm{BW}$ for each extract, and a standard levamisole with the dose of $2.5 \mathrm{mg} / \mathrm{kg} \mathrm{BW}^{15}$ were administered daily for 15 days orally. 1 dose $(0.5 \mathrm{~mL})$ of hepatitis $\mathrm{B}$ vaccine contains HBsAg $10 \mu \mathrm{g}$. Hepatitis B vaccine $(2.6 \mu \mathrm{L} / 20 \mathrm{~g} \mathrm{BW})$ was induced intraperitoneally on the $5^{\text {th }}$ and $12^{\text {th }}$ day. On a day $16^{\text {th }}$, blood was taken from the orbital vein for the measurement of IgG and the hematological profile. The mice were then sacrificed, the liver and spleen organs were taken to calculate their organ index.

\section{Immunomodulatory activities assay}

Assay of immunomodulatory activities were carried out on day 16 : measurement of Immunoglobulin G (IgG) titer, hematological profiles and determine liver and spleen index.

\section{Antibody (lgG) titers assay}

$0,5 \mathrm{~mL}$ of blood samples were collected from the orbital vein of mice. The blood was then centrifuged at $4000 \mathrm{rpm}$ for $10 \mathrm{~min}$, then supernatant (serum) was stored at $-20^{\circ} \mathrm{C}$ until use. The serum was used for the determination of IgG by the enzyme-linked immunosorbent assay ELISA kit (sandwich) method at $450 \mathrm{~nm}$ wavelength (according to the manufacturer's).

\section{Hematological profiles}

Hematological parameters such as RBC (red blood cell), WBC (white blood cell), Hb (hemoglobin), Hct (hematocrit), MCV (mean corpuscular volume), $\mathrm{MCH}$ (mean corpuscular hemoglobin), MCHC (mean corpuscular hemoglobin concentration), Plt (Platelet), was known to be an important component of the immune system. $100 \mu \mathrm{L}$ of blood with the addition of an anticoagulant (titriplex III) were analyzed to determine its hematological profile using a hematology analyzer equipment (Abacus 380, Hungary).

\section{Liver and spleen index}

On the $16^{\text {th }}$ day, $24 \mathrm{~h}$ after the last treatment, mice were sacrificed then liver and spleen organs were taken to calculate their organ index based on the formula below:

Organ index $(\%)=\frac{\text { organ weight }(\mathrm{mg})}{\text { body weight of mouse }(\mathrm{g})} \times 100$

\section{Statistical analysis}

All data (IgG, organ index, hematological parameters) were presented as mean \pm standard error of the mean (SEM). The data were analyzed 
using SPPS statistic program version 22. One-way ANOVA followed by post hoc test the least significant difference (LSD) or the KruskalWallis followed by the Mann-Whitney test, $\mathrm{p}<0.05$ was considered statistically significant.

\section{RESULTS}

\section{Results of phytochemical screening}

Extraction with methanol was aimed to isolate the polar compounds, while fractionation using ethyl acetate was performed in order to take the semipolar compounds. The yield obtained from extraction of Jamaican cherry fruits was $30.30 \%$ for MEJF and $1.49 \%$ for EAFJF. The yield of methanol extract was higher than the ethyl acetate fraction, meaning that Jamaican cherry fruit contained more polar compounds than its semipolar constituents. The results of the phytochemical screening of Jamaican cherry fruit extract can be seen in Table 1 .

\section{Results of immunoglobulin $\mathrm{G}$ titer measurement}

The result of the research showed that MEJF and EAFJF at doses of 50, 100 , and $200 \mathrm{mg} / \mathrm{kg} \mathrm{BW}$ increased the production of immunoglobulin $\mathrm{G}(\mathrm{IgG})$ in a dose-dependent manner compared to the control group $(\mathrm{p}<0.05)$ (Figure 1).

\section{Results of hematological profiles}

Hematological profiles including $\mathrm{RBC}, \mathrm{Hb}, \mathrm{Hct}, \mathrm{MCV}, \mathrm{MCH}, \mathrm{MCHC}$, and Plt were also measured. Based on Table 2, it is shown that the MEJF and EAFJF given for 15 days did not change in the hematological parameters of red blood cells and blood clotting factors (still in the value of normal range).

Table 2 showed that the hematological parameters of MEJF and EAFJF were still within the normal range value, that are erythrocytes (RBC) $9.51 \pm 0.63 \times 10^{6} / \mu \mathrm{L}$, hemoglobin $(\mathrm{Hb}) 17.4 \pm 0.9 \mathrm{~g} / \mathrm{dL}$, hematocrit $(\mathrm{Hct})$ $48.84 \pm 3.4 \%$, MCV 43.6 $\pm 0.6 \mathrm{fL}, \mathrm{MCH} 14.5 \pm 0.2 \mathrm{pg}$, MCHC $33.1 \pm 0.3 \mathrm{~g} /$ $\mathrm{dL}$, platelet (Plt) $427.86 \pm 231.50 \times 10^{3} / \mu \mathrm{L}^{16}$. Thus MEJF and EAFJF did not change the hematological profiles of the mice.

\section{Index of liver and spleen}

Both MEJF and EAFJF could not increase liver index (Table 3). The Present study shows that administration of EAFJF at doses of 50, 100, and $200 \mathrm{mg} / \mathrm{kg}$ BW could increase significantly the spleen weight and spleen index in the mice induced hepatitis $B$ vaccine when compared to control (Table 3). This enhances of spleen weight and spleen index indicate a response to the proliferation of spleen cells (B and $\mathrm{T}$ lymphocytes) which are important in the immune system.

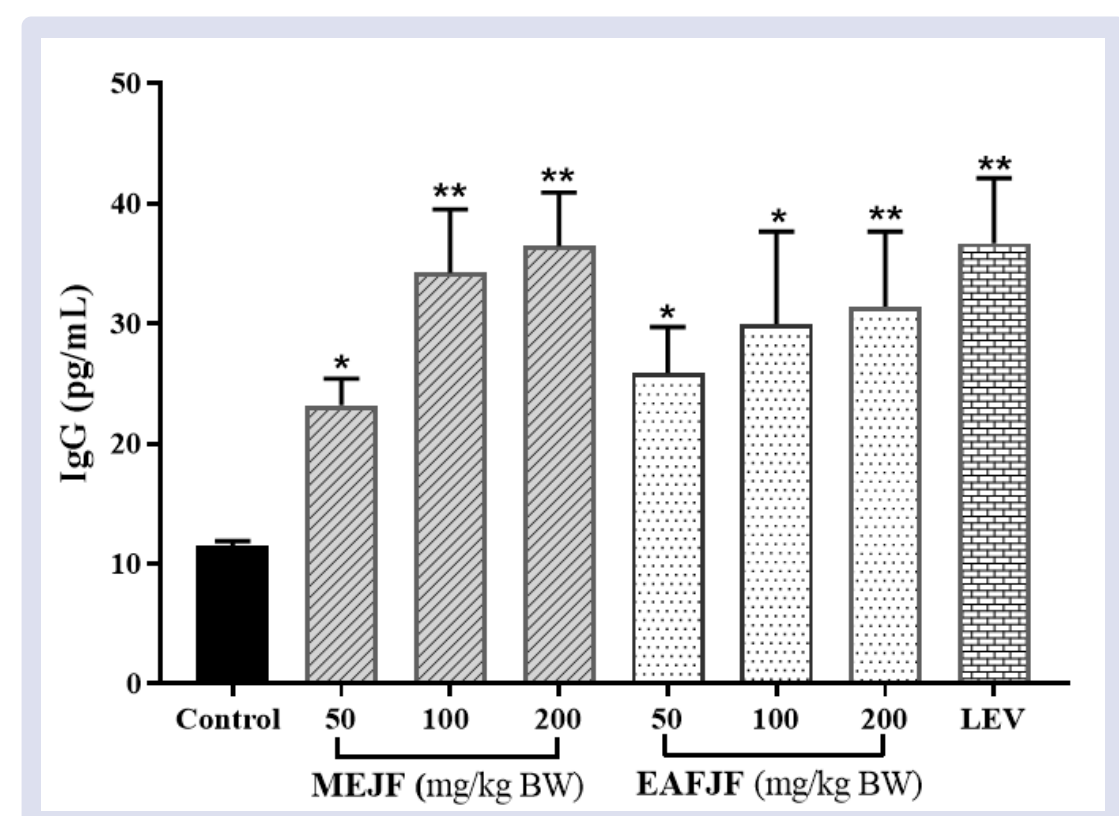

Figure 1: Ig concentration after administration of methanol extract of Jamaican cherry fruits (MEJF) and ethyl acetate fraction of Jamaican cherry fruits (EAFJF). The data were presented as mean $\pm \operatorname{SEM}(n=5) .{ }^{*} p<0.05,{ }^{*} P<0.01$ as compared to control (statistically significant difference).

Table 1: The phytochemical profile of methanol extract of Jamaican cherry fruits (MEJF) and ethyl acetate fraction of Jamaican cherry fruits (EAFJF).

\begin{tabular}{ccc}
\hline Phytochemical compound & MEJF & EAFJF \\
\hline Flavonoid & + & + \\
Alkaloid & + & - \\
Tannin (polyphenol) & + & + \\
Saponin & - & - \\
Steroid & + & + \\
Terpenoid & + & +
\end{tabular}

+ presence; - absent. Based on Table 1, it indicates that MEJF and EAFJF contain flavonoids, polyphenols, steroids, and terpenoids. 
Table 2: Hematological profiles of mice after being treated with Jamaican cherry extract for 15 days.

\begin{tabular}{ccccccccc} 
& $\begin{array}{c}\text { Dose } \\
(\mathrm{mg} / \mathrm{kg})\end{array}$ & $\begin{array}{c}\mathrm{RBC} \\
\left(10^{6} / \mu \mathrm{L}\right)\end{array}$ & $\begin{array}{c}\mathrm{Hb} \\
(\mathbf{g} / \mathrm{dL})\end{array}$ & $\begin{array}{c}\mathrm{Hct} \\
(\%)\end{array}$ & $\begin{array}{c}\mathrm{MCV} \\
(\mathrm{fL})\end{array}$ & $\begin{array}{c}\mathrm{MCH} \\
(\mathbf{p g})\end{array}$ & $\begin{array}{c}\mathrm{MCHC} \\
(\mathrm{g} / \mathrm{dL})\end{array}$ & $\begin{array}{c}\mathrm{Plt} \\
\left(10^{3} / \mu \mathrm{L}\right)\end{array}$ \\
\hline Control & & $12.39 \pm 0.85$ & $17.43 \pm 0.55$ & $51.18 \pm 1.60$ & $41.33 \pm 3.51$ & $14.13 \pm 0.95$ & $34.10 \pm 1.21$ & $460.00 \pm 36.77$ \\
Levamisole & 2.5 & $10.80 \pm 0.90$ & $15.17 \pm 0.23$ & $46.24 \pm 2.28$ & $42.67 \pm 2.08$ & $14.10 \pm 0.95$ & $32.77 \pm 1.58$ & $599.33 \pm 72.83$ \\
MEJF & 50 & $11.69 \pm 0.71$ & $17.57 \pm 0.35$ & $52.50 \pm 1.17$ & $45.00 \pm 3.61$ & $15.07 \pm 0.98$ & $33.47 \pm 0.86$ & $338.33 \pm 112.78$ \\
& 100 & $10.84 \pm 0.26$ & $16.27 \pm 0.58$ & $49.28 \pm 0.84$ & $45.33 \pm 2.08$ & $15.00 \pm 0.87$ & $33.00 \pm 0.75$ & $240.67 \pm 68.16$ \\
& 200 & $10.56 \pm 1.32$ & $16.05 \pm 1.91$ & $48.97 \pm 5.97$ & $46.00 \pm 0.00$ & $15.15 \pm 0.07$ & $32.75 \pm 0.07$ & $406.00 \pm 19.80$ \\
EAFJF & 50 & $10.37 \pm 0.66$ & $14.57 \pm 0.87$ & $47.27 \pm 6.75$ & $45.67 \pm 6.43$ & $14.07 \pm 0.76$ & $31.10 \pm 2.69$ & $348.67 \pm 43.39$ \\
& 100 & $11.20 \pm 0.65$ & $16.37 \pm 1.29$ & $50.40 \pm 3.19$ & $45.00 \pm 0.00$ & $14.57 \pm 0.31$ & $32.47 \pm 0.47$ & $256.33 \pm 95.11$ \\
& 200 & $11.79 \pm 0.81$ & $15.70 \pm 0.78$ & $49.52 \pm 3.33$ & $42.67 \pm 5.69$ & $13.37 \pm 1.55$ & $31.73 \pm 0.57$ & $434.67 \pm 178.24$ \\
\hline
\end{tabular}

MEJF (methanol extract of Jamaican cherry fruits), EAFJF (ethyl acetate fraction of Jamaican cherry fruits), RBC (Red blood cell), Hb (Hemoglobin), Hct (Hematocrit), MCV (mean corpuscular volume), MCH (mean corpuscular hemoglobin), MCHC (mean corpuscular hemoglobin concentration), Plt (platelet). The data were presented as mean \pm SEM $(n=5)$.

Table 3: Data of body weight and organ index of liver and spleen after treatment of Jamaican cherry fruits extract.

\begin{tabular}{ccccccc}
\hline \multirow{2}{*}{ Treatment } & \multirow{2}{*}{ Dose $(\mathrm{mg} / \mathbf{k g})$} & $\begin{array}{c}\text { Mice body weight } \\
\text { (g) }\end{array}$ & \multirow{2}{*}{ Weight of liver $(\mathbf{g})$} & $\begin{array}{c}\text { Weight of spleen } \\
(\mathbf{g})\end{array}$ & \multicolumn{2}{c}{ Organ index } \\
\cline { 5 - 7 } & & $29.60 \pm 5.51$ & $1.120 \pm 0.40$ & $0.087 \pm 0.033$ & $3.74 \pm 0.85$ & $0.294 \pm 0.09$ \\
Control & & $28.05 \pm 2.12$ & $1.403 \pm 0.21$ & $0.195 \pm 0.046$ & $5.01 \pm 0.73$ & $0.695 \pm 0.10^{*}$ \\
Levamisole & 2.5 & $29.03 \pm 2.92$ & $1.266 \pm 0.18$ & $0.081 \pm 0.016$ & $4.35 \pm 0.27$ & $0.280 \pm 0.05$ \\
MEJF & 50 & $30.80 \pm 2.42$ & $1.451 \pm 0.37$ & $0.122 \pm 0.034$ & $4.66 \pm 0.81$ & $0.395 \pm 0.09$ \\
& 100 & $29.32 \pm 2.95$ & $1.290 \pm 0.20$ & $0.117 \pm 0.025$ & $4.42 \pm 0.67$ & $0.403 \pm 0.08$ \\
& 200 & $27.25 \pm 6.19$ & $1.495 \pm 0.22$ & $0.185 \pm 0.044$ & $5.58 \pm 0.57$ & $0.693 \pm 0.15^{*}$ \\
EAFJF & 50 & $32.58 \pm 2.06$ & $1.556 \pm 0.21$ & $0.196 \pm 0.036$ & $4.76 \pm 0.39$ & $0.601 \pm 0.09^{*}$ \\
& 100 & $29.15 \pm 4.57$ & $1.378 \pm 0.26$ & $0.175 \pm 0.040$ & $4.72 \pm 0.40$ & $0.620 \pm 0.19^{*}$ \\
\hline
\end{tabular}

MEJF (methanol extract of Jamaican cherry fruits), EAFJF (ethyl acetate fraction of Jamaican cherry fruits). The data were presented as mean \pm SEM $(\mathrm{n}=5){ }^{*} \mathrm{p}<0.05$ as compared to control (statistically significant difference)

The spleen index was increased in the EAFJF group, these results showed that the immune response of hepatitis vaccine-induced mice were stimulated after administration of the EAFJF for 15 days.

\section{DISCUSSION}

The phenolic and flavonoid content in the MEJF and EAFJF are thought to be responsible for its immunomodulatory activity. Table 1 showed that Jamaican cherry fruits (ripe) contain phenolics and flavonoids. These were in line with previous research ${ }^{17}$. According to Ragasa et al, steam distillations of M. calabura L. fruit followed by GC/MS analysis indicating constituents such as phenolic compounds (11.3\%), esters (31.4\%), alcohol (15.9\%), sesquiterpenoids (10.6\%), and furan derivatives $(8.3 \%)^{18}$. The methanol extract of the leaves, bark, and fruit of M. calabura L. contain glycosides and flavonoids as the main biologically active compounds ${ }^{19}$. Jamaican cherry one of the low caloric fruits and attractive in both color and flavor. Jamaican cherry fruit also have nutritional value by it content such as protein $6,52 \%$, crude fiber $18,43 \%$, crude fat $10,47 \%^{20}$. On top of that, Jamaican cherry fruits have bioactive compounds with various pharmacological activities. Thus Jamaican cherry fruits were potential to be used as functional food ${ }^{21}$.

MEJF and EAFJF that contain flavonoids are thought to have immunomodulatory effects. This is in line with the previous research that some flavonoids increase immune response by stimulating antibody production ${ }^{22}$. Based on the results above, it is proved that Jamaican cherry fruits have an immunomodulatory effect by stimulating antibody production (immunoglobulin G). This is possible because Jamaican cherry fruit contains phenolic components such as gallic acid. Pereira et al demonstrated that gallic acid is phenolic compound that is abundant in Jamaican cherry (M. calabura L.) fruits ${ }^{21}$. Other research reported that pre-treatment with gallic acid has effectively decreased the immune suppression induced by immunosuppressive drugs such as cyclophosphamide and cisplatin in mice. Moreover, gallic acid enhanced antibody titer effects. This indicates that humoral immune response can be facilitated by gallic acid ${ }^{23}$. In addition, Jamaican cherry fruit also contains flavonoids in the form of flavanols in large quantities such as gallocatechin and flavonols such as quercetin in small amounts $^{21}$. This flavonoid content is thought to be responsible for the immunomodulatory effect ${ }^{9}$.

Lymphocytes consist of both naive (inactivated) and activated T cells and B cells. When an antigen is detected by a dendritic cell, a cell that is responsible for antigen recognition (antigen presenting cells), naive $\mathrm{T}$ and $\mathrm{B}$ cells in the bone marrow will enter the secondary lymphoid organs such as lymph nodes and spleen. B cells are activated by antigens to become effector cells and memory cells, then the active cells will migrate to the peripheral tissue where infection occurs ${ }^{1}$. Lymphocytes consist of $\mathrm{B}$ cells and $\mathrm{T}$ cells that are components of the immune system. Circulation of lymphocytes are not only in blood and lymphoid vessels but also in lymphoid organ. The spleen is one of the secondary (peripheral) lymphoid organs where place for keeping the mature naive lymphcytes ${ }^{24}$. EAFJF could increase spleen index, this enhances of spleen weight and spleen index indicate a response to the proliferation of spleen cells (B and T lymphocytes) which are important in the immune system. Previous research stated that the proliferation of B-lymphocytes contributes to increasing of spleen weight (positively correlated by $73.3 \%)^{25}$.

The liver has many functions including synthesis and metabolism. Apart from that, the liver is also responsible for removing foreign material. Immaculata et al stated that increasing liver weight is thought to increase the number of phagocytic cells because Kupffer cells of the liver have the main role for eliminating antigen ${ }^{26}$. Both MEJF and EAFJF could not increase liver index.

The hepatitis B vaccine acted as an antigen that could induce the production of anti-HBs antibodies that provide immunity against 
hepatitis B. It was chosen because it is safer than the active hepatitis virus $^{27}$. The anti-HBs antibody measured was IgG, a high amount of IgG indicates a chronic response ${ }^{28,29}$. Mice were induced with the hepatitis B vaccine which aimed to generate effective immunity to form immunoglobulins and memory cells. Specific immune response tests are carried out by measuring the production of immunoglobulin $\mathrm{G}$ which aims to determine the humoral immune response mediated by antibodies. Antibodies play role as an effector of the humoral response by binding and neutralizing antigens or by facilitating the elimination of antigens that can be destroyed by phagocytes ${ }^{30}$. Measurement of IgG levels was undergone on day $16^{\text {th }}$ because the antibody level reaches its peak in 7-10 days after the antigen entered. When there is repeated antigen entry the antibody level reaches its peak in 3-5 days after repeated infection, IgG level rise much higher and lasts longer ${ }^{1}$. IgG levels produced by the treated groups of Jamaican cherry fruits extract and levamisole showed that Jamaican cherry fruits with doses of 100 and $200 \mathrm{mg} / \mathrm{kg}$ BW could increase IgG production that equivalent to levamisole $(\mathrm{p}>0.05)$. This proves that MEJF and EAFJF can stimulate the humoral immune system.

In this research, there were no significant differences in the hematological parameter between the treatment and control groups. Both MEJF and EAFJF did not influence the hematological profiles. Although some hematological parameter values have changed, such as the platelet values, the changes are still within the normal range value ${ }^{16}$.

\section{CONCLUSION}

The methanol extract of Jamaican cherry (M. calabura L.) fruits (MEJF) and ethyl acetate fraction of Jamaican cherry fruits (EAFJF) have immunostimulatory activity by inducing the production of IgG antibodies without changing the hematological profile. The treatment with EAFJF could increase the spleen organ index. This finding suggests that Jamaican cherry fruits have a beneficial effect on the immune system as immunostimulant.

\section{ACKNOWLEDGMENT}

We thank the Ministry of Research, Technology, and Higher Education of the Republic of Indonesia for research funding PDUPT in 20192020. PT Konimex for providing levamisole (pharmaceutical grade).

\section{CONFLICTS OF INTEREST}

All authors declare that there is no conflicts of interest.

\section{REFERENCES}

1. Abbas AK, Lichtman AH, Pillai S. Cellular and molecular immunology e-Book. Ninth. Philadelphia: Elsevier; 2018.

2. Preethi K, Premasudha P, Keerthana K. Anti-inflammatory activity of Muntingia calabura fruits. Pharmacogn J. Pharmacognosy Network Worldwide [Phcog.Net]; 2012;4(30):51-6.

3. Sarimanah J, Ketut Adnyana I, Sukandar EY, Kurniati NF. The antirheumatic activity of Muntingia calabura L. Leaves ethanol extract and its fraction. Asian J Pharm Clin Res. 2017;10(1):84-6.

4. Preethi K, Vijayalakshmi N, Shamna R, Sasikumar JM. In Vitro Antioxidant Activity of Extracts from Fruits of Muntingia calabura Linn . from India. Pharmacogn J. Pharmacognosy Network Worldwide [Phcog.Net]; 2010;2(14):11-8.

5. Siddiqua A, Premakumari KB, Sultana R, Vithya, Savitha. Antioxidant activity and estimation of total phenolic content of Muntingia calabura by colorimetry. Int J ChemTech Res. 2010;2(1):205-8.

6. Haerani A, Chaerunisa AY, Subarnas A. Antioxidant Activities of Muntingia calabura, Syzygium cumini, Ocimum basilicum, and Eleutherine bulbosa using DPPH Method. Indones J Pharm. 2019;1(2):57-61.
7. Pramono VJ, Santoso R. Effect of Keren Fruit Extract (Muntingia calabura) on Blood Glucose Levels of Rats (Rattus norvegicus) which Induced by Streptozotocin (STZ). 2014;32(2):218-23.

8. Sujono TA, Kusumowati ITD, Munawaroh R. Immunomodulatory Activity of Muntingia calabura L Fruits using Carbon Clearance Assay and Their Total Flavonoid and Phenolic Contents. Asian J Pharm Clin Res. 2020;13(2):140-5.

9. Jantan I, Ahmad W, Bukhari SNA. Plant-derived immunomodulators: An insight on their preclinical evaluation and clinical trials. Front Plant Sci. 2015;6(AUG):1-18.

10. Patel S, Vajdy M. Induction of cellular and molecular immunomodulatory pathways by vitamin A and flavonoids. Expert Opin Biol Ther. Informa UK, Ltd.; 2015;15(10):0.

11. Lin JT, Chen YC, Chang YZ, Chen TY, Yang DJ. Effective compounds in the fruit of: Muntingia calabura Linn. cultivated in Taiwan evaluated with scavenging free radicals and suppressing LDL oxidation. Food Funct. 2017;8(4):1504-11.

12. Grigore A. Plant Phenolic Compounds as Immunomodulatory Agent. In: Phenolic Compound-Biological Activity. 2017;75-88.

13. Krishnaveni M, Dhanalakshmi R. Qualitative and Quantitative Study of Phytochemicals in Muntingia calabura L. Leaf and Fruit. World J Pharm Res. 2014;3(6):1687-96.

14. Yadav P, Kumar A, Mahour K, Vihan VS. Phytochemical Analysis of Some Indiegenous Plants Potent Againts Endoparasite. J Adv Lab Res Biol. 2010;1 (I):56-9.

15. Singh S, Yadav CPS, Noolvi MN. Immunomodulatory activity of butanol fraction of Gentiana olivieri Griseb. on Balb/C mice. Asian Pac J Trop Biomed. 2012;2(6):433-7.

16. Restel TI, Porfirio LC, Souza AS de, Silva IS. Hematology of Swiss mice (Mus musculus) of both genders and different ages. Acta Cir Bras. 2014;29(5):306-12

17. Singh R, lye S, Prasad S, Deshmukh N, Gupta U, Zanje A, et al. Phytochemical Analysis of Muntingia calabura Extracts Possessing Anti-Microbial and Anti-Fouling Activities. Int $J$ Pharmacogn Phytochem Res. 2017;9(6):826-32.

18. Ragasa CY, Tan MCS, Chiong ID. Chemical Constituents of Muntingia calabura Chemical constituents of Muntingia calabura L . Der Pharma Chem. 2015;7(5):136-41.

19. Sibi G, Naveen R, Dhananjaya K, Ravikumar KR, Mallesha H. Potential use of Muntingia calabura L. extracts against human and plant pathogens. Pharmacogn J. Pharmacognosy Network Worldwide [Phcog.Net]; 2012;4(34):44-7.

20. Kassim N, Hambali K, Amir A. Nutritional Composition of Fruits Selected by Long-Tailed Macaques (Macaca fascicularis) in Kuala Selangor, Malaysia. Trop life Sci Res. 2017;28(100):91-101.

21. Pereira GA, Arruda HS, Morais DR de, Eberlin MN, Pastore GM Carbohydrates, volatile and phenolic compounds composition, and antioxidant activity of calabura (Muntingia calabura L.) fruit. Food Res Int. Elsevier; 2018;108(March):264-73.

22. Martínez G, Mijares MR, Sanctis JB De. Effects of Flavonoids and Its Derivatives on Immune Cell Responses. Recent Pat Inflamm Allergy Drug Discov. 2019;13(2):84-104.

23. Shruthi S, Vijayalaxmi K., Shenoy BK. Immunomodulatory effect of gallic acid againts cyclophosphamide and cisplatin induced immunosuppression in swiss albino mice. Indian $\mathrm{J}$ Pharm Sci. 2018;80(1):150-60.

24. Murphy K, Weaver C. Janeway's Immunobiology. 9th ed. New York and London: Taylor \& Francis Group; 2017.

25. Wahyuningsih SPA, Pramudya M, Putri IP, Savira NII, Winarni D, Suhargo L, et al. Okra Polysaccharides Improves Spleen Weight and B-Lymphocytes Proliferation in Mice Infected by Staphylococcus aureus. Biosaintifika J Biol Biol Educ. 2017;9(3):460.

26. Iwo MI, Soemardji AA, Retnoningrum DS, Sukrasno, Ua UM. Immunostimulating effect of Pule (Alstonia scholaris L. R.Br., Apocynaceae) bark extracts. Clin Hemorheol Microcirc. 2000;23(24):177-83. 
27. Das S, Ramakrishnan K, Behera SK, Ganesapandian M, Xavier AS, Selvarajan S. Hepatitis b vaccine and immunoglobulin: Key concepts. J Clin Transl Hepatol. 2019;7(2):165-71.

28. Rath S, Devey ME. IgG subclass composition of antibodies to HBsAg in circulating immune complexes from patients with hepatitis B virus infections. Clin exp Immunol. 1988;72:164-7.
29. Lebray P, Vallet-Pichard A, Michel ML, Fontaine H, Sobesky R, Bréchot $C$, et al. Immunomodulatory drugs and therapeutic vaccine in chronic hepatitis B infection. J Hepatol. 2003;39(SUPPL. 1):151-9.

30. Dashputre NL, Naikwade NS. Immunomodulatory Activity of Abutilon Indicum linn on Albino Mice. Int J Pharma Sci Res. 2010;1(3):178-84.

\section{GRAPHICAL ABSTRACT}

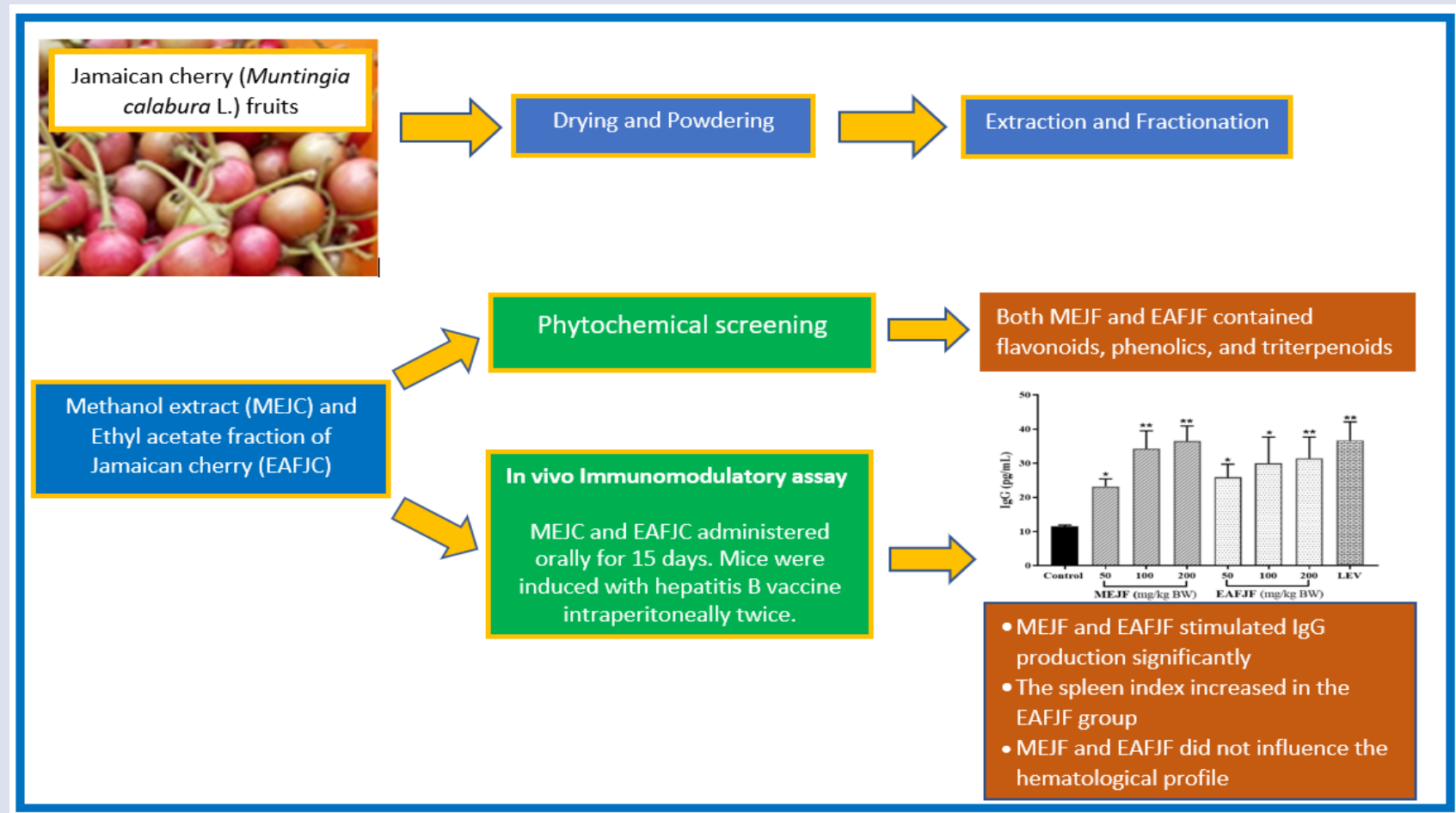

\section{ABOUT AUTHORS}

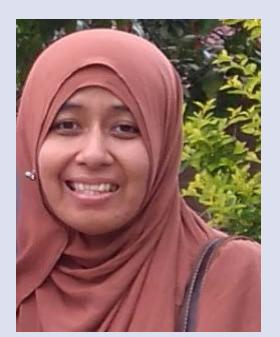

\section{Tanti Azizah Sujono}

Lecturer at the Faculty of Pharmacy, Universitas Muhammadiyah Surakarta, Indonesia. Research interests are pharmacology and toxicology. Her current research focuses on studies immunomodulators from plants and preclinical studies.

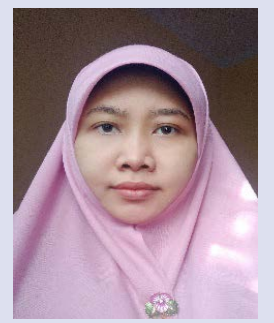

\section{Ika Trisharyanti Dian Kusumowati}

Lecturer at Faculty of Pharmacy, Universitas Muhammadiyah Surakarta, Indonesia. Research interests in herbal medicine, analytical chemistry, drug discovery, and drug development. 


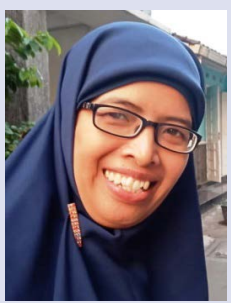

\section{Rima Munawaroh}

Lecturer at the Faculty of Pharmacy, Universitas Muhammadiyah Surakarta, Indonesia. Research interests are pharmacognosy-phytochemistry. Her current research focuses on the isolation and identification of immunomodulatory compounds from plants.

Cite this article: Sujono TA, Kusumowati ITD, Munawaroh R. Effects of Jamaican cherry (Muntingia calabura L.) Fruits Extract on Immunoglobulin G Levels and Hematological Profiles in Mice. Pharmacog J. 2021;13(2): 535-41. 